\title{
$\operatorname{ACLSV(Apple~chlorotic~leafspot~virus)~ㄱㅏㅁㅇㅕㅁㅇㅣ~ㅅㅏㄱㅘ~'ㅎㅗㅇㄹㅗ'~ㅍㅜㅁㅈㅗㅇㅇㅢ~}$ 과실품질에 미치는 영향
}

\author{
김현란* - 김정수 · 황정환 ${ }^{1} \cdot$ 이신호 · 최국선 · 최용문 ${ }^{2}$ \\ 농촌진흥청 원예연구소 원예환경과, '원예연구소 과수과, ${ }^{2}$ 원예연구소 원예기술지원과
}

\section{Influence of ACLSV-infection on Fruit Quality of 'Hongro' Apples}

\author{
Hyun Ran Kim*, Jeong Soo Kim, Jeong Hwan Hwang', Sin Ho Lee, \\ Gug Seon Choi and Yong Mun Choi ${ }^{2}$ \\ Horticultural Environment Division, National Horticultural Research Institute, Rural \\ Development Administration, Suwon 441-440, Korea \\ ${ }^{1}$ Fruit Research Division, NHRI, RDA. \\ ${ }^{2}$ Horticultural Technology Transfer Division, NHRI, RDA.
}

(Received on April 9, 2004)

\begin{abstract}
'Hongro' is one of the most important apple cultivars whose growing area is increasing because of its good quality. Recently fruit shrinking symptom causing decrease of fruit size, juice, and quality, appears in some commercial 'Hongro' orchards. The average frequency of occurrence of fruit shrinking symptom was $12 \%$ of total trees investigated and Apple chlorotic leaf spot virus (ACLSV) was detected from all the trees showing fruit shrinking symptom by ELISA. A typical virus infection symptom of leaf epinasty and stem necrosis appeared on woody indicators, Spy227 and Virginia crab grafted with infected trees and all the grafted trees showed positive reaction to ACLSV antiserum by ELISA. It was proved that ACLSV can be easily transmitted by grafting. ACLSV was also isolated from the leaves of $C$. quinoa inoculated with sprouting leaf sap of infected trees. To prove that the fruit shrinking symptom was caused by ACLSV infection, ACLSV-infected scion was grafted on virus-free 'Hongro/M9' and the fruit characteristics were investigated. Consequently the same symptoms of fruit size and juice decreasing were observed from the trees grafted with ACLSV-infected scion. Therefore, it is suggested that the fruit shrinking symptom is caused by ACLSV infection and 'Hongro' can be classified as sensitive cultivar to ACLSV.
\end{abstract}

Keywords : Apple, ACLSV, Fruit Quality, Hongro

사과 ‘홍로' 품종은 농촌진홍청 원예연구소에서 육성한 국내 신품종으로 1980년에 '스퍼어리블레이즈' 품종과 스퍼골든데리셔스' 품종을 교배하여 1988년에 '홍로'로 명명된 품종이다. 1990년대 초반부터 재배되기 시작하여 현재 약 $2,000 \mathrm{ha}$ 로 국내 재배면적의 약 11 12\%를 차지 하면서(농림부 과수실태조사, 2002) 점차 증가추세에 있 으며 재배농민과 소비자들에게 선호도가 높은 유망 품종 기다. 하지만 최근 들어 '홍로' 품종 재배과원에서 여러 가지 문제점들이 제기되고 있는데 그 중 하나가 과실이

:Corresponding author

Phone)+82-31-290-6235, Fax)+82-31-290-6259

E-mail)kimhr0@rda.go.kr
작아지고 딱딱해지면서 숙기가 늦어지는 소과증상이다. 이러한 증상은 1994년경에 처음 관찰된 이후 점차 증가 되고 있으며 사과 재배 농가들 사이에서는 속칭 '개홍로' 혹은 '돌홍로'로 일컬어지고 있다. 과실크기가 작아지면 서 육질이 치밀하고 딱딱해지는 소과증상에 대해서 초기 에는 재배 및 생리적인 측면에서의 검토가 이루어진 바 있었으나 토양분석과 과실, 잎의 무기성분 분석 둥에서 정상주와의 유의한 차이는 없는 것으로 확인되었다(김 등, 1996). 이후 발생농가에서 이상중상 발생주에 대한 조치 로 정상적인 과실이 결실되는 가지를 고접을 하였으나 마 찬가지로 고접된 가지에서도 이상 과실이 결실되는 것이 확인되어 접목전염되는 것으로 추정되었다. 따라서 바이 러스 등 접목전염성 병원체 감염에 관한 검토가 요구되 
었으며 본 연구를 통하여 홍로과실의 바이러스병의 감염 과 인위적인 바이러스 접종에 의한 결실과실의 반응연구 를 수행함으로써 홍로 소과증상과 바이러스병 감염과의 관련성을 검토하였다.

\section{재료 및 방법}

홍로 이상중상 발생조사 및 바이러스 검정. 경상도, 충청도 지역의 홍로품종을 재배하는 사과재배 농가 과원 에서 소과증상이 발생되는 나무의 빈도를 조사하고, 이들 발생주를 대상으로 신엽 및 꽃조직을 채취하여 바이러스 감염여부를 진단하였다. 바이러스 김정은 ACLSV, ASGV, ApMV를 ELISA 진단하였으며 스위스 Bioreba사의 항체 를 이용하였다. 접목전염성 검정은 발생과원에서 발생가 지를 모두 잘라내고 정상주의 가지를 고접한 다음 고접 가지에서 발아한 신엽과 꽃, 과실을 바이러스 진단하였다. 또한 소과증상 발생주의 신엽조직을 Chenopodium quinoa 에 접종하여 바이러스를 분리하였으며 분리된 바이러스는 전자현미경 검경, ELISA 및 RT-PCR진단을 수행하였다. RT-PCR 진단을 위해 외피단백질 유전자 부위를 기준으 로 ACLSV-CPf로 5'GAGAGTTTCAGTTTGCTAGACA3', ACLSV-CPr로 5'GCAAATTCAGTCTGTAAAAG3'의 염기 서열로 디자인된 primer set를 사용하였다. 바이러스 감 수성인 Spy227 등 3종의 목본 지표식물 품종에 소과발생 주의 가지 목질부 조직을 일부 포함한 수피조직을 접목 접 종한 다음 접종 2 년차까지 병징의 발현정도를 관찰하였다.

홍로 이상중상 발생과실 과육조직의 전자현미경 검경 및 과실톡성 검정. 홍로 소과증상을 나타내는 과실의 과 육조직을 $1 \mathrm{~cm} \times 1 \mathrm{~cm}$ 정사각형으로 잘라 주사전자현미경 (Hitachi)으로 과육조직을 검경하였으며, 정상과실의 과육 조직도 동일하게 검경하였다. 소과의 과실특성은 충주, 괴 산지역의 발생농가에서 9월 수확기에 채취한 과실을 대 상으로 과실크기, 당도, 경도 등을 조사하였으며 과실특 성 조사는 농촌진홍청 기준방법을 사용하였다.

바이러스 인위접종 및 결실과의 과실반응 조사. 바이 러스 무독주 3 년생 나무에 ACLSV 등 2종의 바이러스가 단독 또는 복합 감염되어 있는 감염주의 수피를 '02년 5 월에 접목접종한 후 2 년간 잎에서의 바이러스 검출농도 와 결실과실의 반응을 조사하였다.

\section{결과 및 고찰}

경남북 및 충남북지역의 주요 사과 재배지역을 대상으 로 홍로품종에서의 소과증상 발생율을 조사한 결과 농가
Table 1. Frequency of occurrence of fruit shrinking symptoms in several 'Hongro' apple orchards

\begin{tabular}{lccc}
\hline \hline \multirow{2}{*}{ Orchard } & \multicolumn{3}{c}{ Percentage of infected trees $(\%)$} \\
\cline { 2 - 4 } & 2001 & 2002 & 2003 \\
\hline Okcheon & 30 & 36 & 40 \\
Chungju & 6 & 7 & 10 \\
Gyeongsan & 50 & 50 & -2 \\
\hline
\end{tabular}

${ }^{z}$ Trees were removed.

Table 2. Virus diagnosis between infected and healthy trees by ELISA

\begin{tabular}{lcccc}
\hline \hline \multirow{2}{*}{$\begin{array}{c}\text { State of tested } \\
\text { trees }\end{array}$} & No. & \multicolumn{3}{c}{ Percentage of positive reactions } \\
\cline { 3 - 5 } of trees & ACLSV & ASGV & ApMV \\
\hline With symptom & 23 & $23(100.0 \%)$ & $5(21.7 \%)$ & $0(0.0 \%)$ \\
No symptom & 134 & $21(15.7 \%)$ & $10(7.5 \%)$ & $4(3.0 \%)$ \\
\hline
\end{tabular}

*Young leaves and/or floral tissues were tested.

에 따라서 홍로 재배주수의 $5 \%$ 정도에서 많이 발생한 농 가는 $50 \%$ 까지 발생되고 있는 것으로 조사되었다(성적 미 기재). 2000년부터 2003년까지 4년간 옥천, 안동, 괴산 등 15 개 시군, 20 개 농가에서 $12 \%$ 정도로 홍로 소과증상 발 생이 확인되었다. 특히 주요 발생농가에서 매년 발생증가 율을 조사한 결과 Table 1에서와 같이 매년 1 6\% 정도 로 증가하고 있었으며 발생율이 특히 높은 경산 농가의 경우 사과재배를 포기하고 다른 과종으로 변경할 정도로 심각한 피해를 주고 있었다.

소과 증상이 발생하는 나무들을 대상으로 건전한 나무 와 비교하여 바이러스 감염여부를 ELISA 진단한 결과 소 과 발생주에서 $100 \% \mathrm{ACLSV}$ 감염이 확인되었으며, $\mathrm{ASGV}$ 는 $21 \%, \mathrm{ApMV}$ 는 $0 \%$ 로 비교적 감염율이 낮은 편이었다 (Table 2). 특히 소과발생주를 폐기하기 위해 주간을 절단 한 나무에서 나온 흡지(吸枝)를 바이러스 진단한 결과 ACLSV에 대한 ELISA 홉광도가 특이적으로 높게 나타 나 (성적 미기재) 소과발생 관련성을 예측할 수 있었다. 바이러스 농도가 매우 낮았던 나무에서도 ACLSV 농도 가 점차적으로 높아지면서 과실에 영항을 미쳐 Table 1 의 결과와 같이 연차적으로 소과 발생율이 높아지는 것 으로 추정되었다. 하지만 바이러스 농도수준과 과실에 미 치는 영향에 관해서는 실시간 진단기술을 이용한 수체내 의 바이러스농도 정량화 연구가 보완되어야 할 것으로 판 단된다. ACLSV는 사과 고접병의 병원 바이러스 중의 하 나로, 특이적으로 Malus prunifolia Borkh. var. ringo Asami(Maruba kaido)를 대목으로 사용하였을 경우에 심 한 수량감소를 가져온 것으로 보고되어 있다(Yanase 등, $1975,1979)$. 일반적으로 다른 품종이나 대목종에서는 잠 

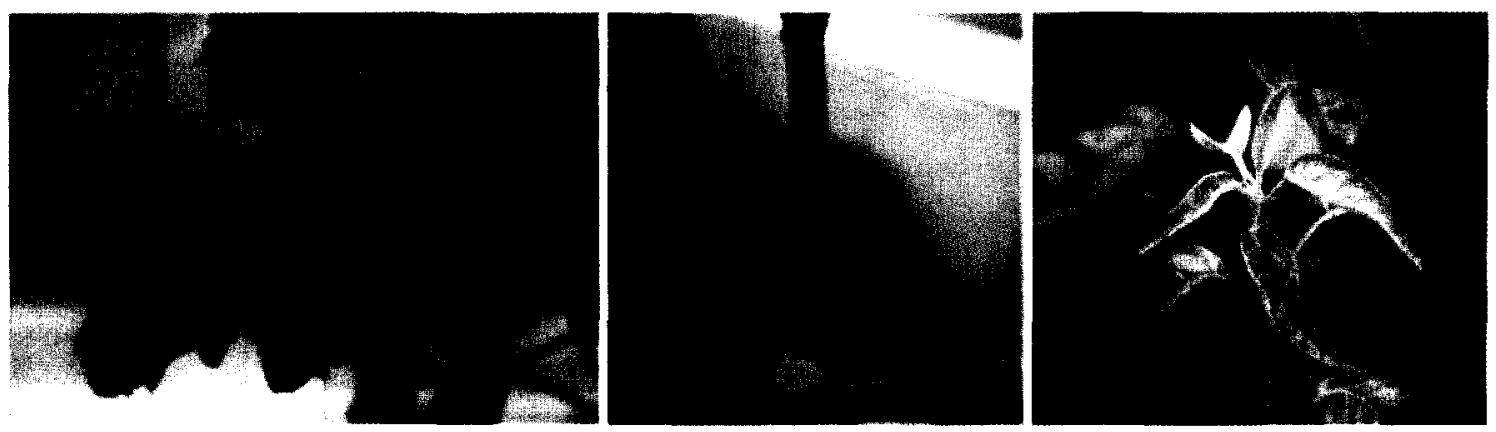

Fig. 1. Symptoms on several indicators inoculated with infected Hongro's sprouting leaves or bark tissues (A, Line pattern mosaic on Chenopodium quinoa ; B, Stem necrosis on Spy227; C, Leaf epinasty and stem necrosis on Virginia crab).

Table 3. Comparison of fruit characteristics between infected and bealthy fruits collected from several orchards

\begin{tabular}{llccccl}
\hline \hline Orchard & Fruits & $\begin{array}{c}\text { Fruit } \\
\text { weight } \\
(\mathrm{g})\end{array}$ & $\begin{array}{c}\text { Hardness } \\
(\mathrm{kgf} / \\
\varnothing 5 \mathrm{~mm})\end{array}$ & $\begin{array}{c}\text { SSC } \\
\left({ }^{\circ} \mathrm{Bx}\right)\end{array}$ & $\begin{array}{c}\text { Acidity } \\
(\%)\end{array}$ & $\begin{array}{l}\text { Amount } \\
\text { of juice }\end{array}$ \\
\hline \multirow{2}{*}{ Okcheon } & Infected & 188.6 & 3.7 & 13.4 & 0.20 & Minimun \\
& Healthy & 352.5 & 3.0 & 12.9 & 0.20 & Plenty \\
\hline \multirow{2}{*}{ Chungju } & Infected & 156.0 & 4.4 & 14.1 & 0.22 & A little \\
& Healthy & 282.7 & 3.3 & 14.3 & 0.16 & Plenty \\
\hline \multirow{2}{*}{ Guesan } & Infected & 145.2 & 4.0 & 15.1 & 0.21 & Minimun \\
& Healthy & 190.8 & 3.6 & 14.5 & 0.16 & Plenty \\
\hline
\end{tabular}

복 감염되어 외형적으로 큰 피해를 나타내지 않았으나 최 근 들어서는 M.9 등 왜성대목의 사용이 확대되면서 바이 러스병의 감염이 계속 확인되고 있으며 그 피해도 보고 되고 있다(김, 2001). 따라서 특히 홍로품종의 경우 다른 품종에 비해 ACLSV에 대한 감수성이 높아 바이러스 증 식도 빠르고 과실에 미치는 영향도 커서 경제적 피해도 가 비교적 큰 것으로 추측할 수 있었다. 소과증상을 나타 내는 과실을 Table 3에서와 같이 옥천, 충주, 괴산농가에 서 채집하여 정상과와 비교한 결과, 농가 간에 다소 차이 가 있었으나 소과 과실크기가 정상과의 $53 \sim 76 \%$ 정도였 으며 과실 경도는 11 33\% 더 딱딱한 것으로 조사되었다. 당도나 산도는 유의한 차이가 없었으나 과즙량에 있어서

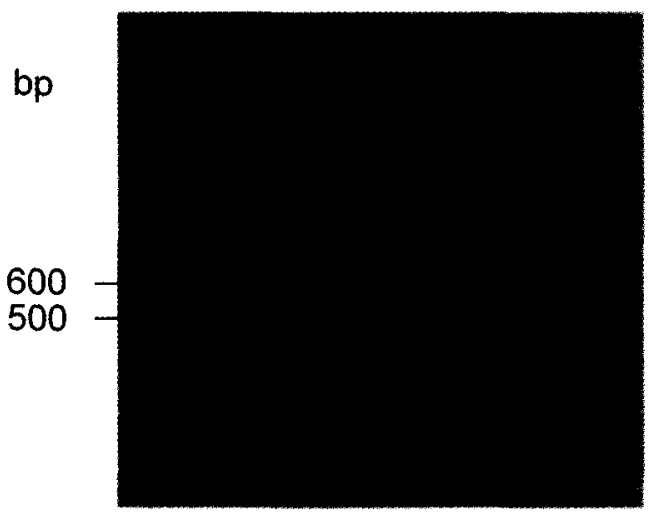

Fig. 2. Agarose gel electrophoresis of RT-PCR products from leaf of infected 'Hongro' apple and C. quinoa inoculated with leaf of infected apple. M, size marker ( $100 \mathrm{bp}$ ladder); lane 1 , infected apple leaf; lane 2 , healthy apple leaf; lane 3 , line pattern mosaic leaf of C. quinoa.

소과의 경우 거의 과즙추출이 안될 정도로 과즙량이 극 히 작았다.

소과증상의 과실이 결실된 가지의 신엽조직과 수피조 직을 이용한 생물검정에서는 C. quinoa의 접종엽에 mottle 증상이 나타나면서 상엽으로 진전되어 라인모앙의 모자 이크 병징을 나타내는 바이러스가 분리되었으며(Fig. 1A) 이를 증식하여 전자현미경 및 항혈청을 통하여 사상형 입 자와 ACLSV에 대한 혈청반응을 확인할 수 있었다(성적
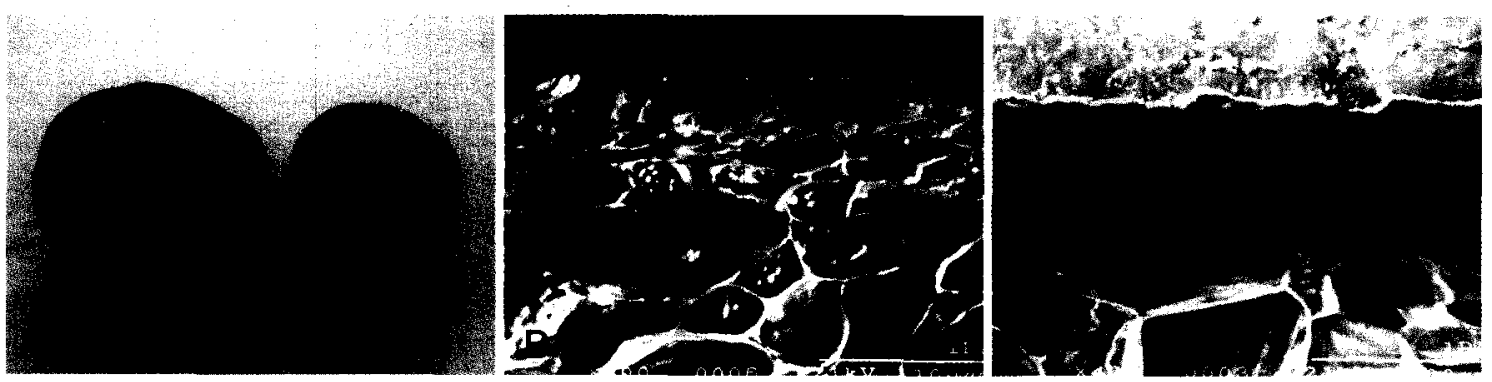

Fig. 3. Comparison of fruit size and coloring between normal fruit (left of A) and infected fruit (right of A) and micrographs examined by scanning electromicroscope between infected (B-1) and healthy (B-2) flesh tissues of 'Hongro' fruits. 
미기재). ACLSV 특이 프라이머를 이용한 RT-PCR에서는 약 $566 \mathrm{bp}$ 크기의 증폭산물을 언을 수 있었다(Fig. 2). 목 본 지표식물을 이용한 검정에서는 건전한 접수를 접종한 처리주에서는 특이 증상이 관찰되지 않은 반면에 소과 발 생주를 접종한 처리에서는 이듬해 발아한 Spy227품종 신 엽에서부터 잎의 상편생장이 나타났고 Virginia crab품종 에서는 접종부분의 줄기가 괴사되면서 점차 고사하는 것 이 관찰됨으로써 접목전염성을 확인할 수 있었다(Fig. 1B and C). 잎의 상편생장과 수피괴사는 사과 고접병과 관련 된 $\mathrm{ACLSV}, \mathrm{ASGV}$ 를 접종했을 때 나타나는 병징(김 등, 1998)과 유사하였다.

착색성이 우수한 홍로품종(신 등, 1989)에서 Fig. 3A의 우측과실에서와 같이 과실의 착색이 정상과에 비해 1개 월 이상 늦어져서 조생종 품종으로 가치가 높은 홍로품 종의 경우 수확적기를 놓침으로써 거의 수익성이 없어져 서 재베농민에게 피해를 주고 있다. 세포 수나 세포크기 의 차이룰 검토해 보고자 수행한 과육조직의 주사전자현 미경 검경에서는 단위면적당 세포 수에서는 큰 차이가 없 었으나 정상과의 세포는 세포모양이 잘 유지되어 있는 것 에 반해 소과의 세포는 세포모양이 찌그러지면서 속에는 전분립으로 추정되는 알갱이가 가득 차 있는 세포들이 많 이 관찰되었다(Fig. 2B). 과육조직 내 전분립의 축적은 과 실크기 및 딱딱함과 관련성이 있을 것으로 추정되지만 추 가적인 보완연구가 필요할 것으로 생각된다. 홍로 소과증 상과 $\mathrm{ACLSV}$ 감염과의 관련성을 최종적으로 검토하기 위 하여 바이러스 인위접종에 의한 시험을 수행한 결과, Table 4와 같이 ACLSV 단독 접종한 나무에서 착과된 과실이 과실크기가 건전과에 비해 약 $20 \%$ 작고 과실 착색진전 도도 느려 소과 증상이 발현되는 것으로 관찰되었으며, 다소 감염 바이러스 농도가 낮은 $\mathrm{ACLSV}, \mathrm{ASGV}$ 복합처 리구에서는 소과증상이 발현되지 않는 것으로 관찰되어 바이러스 농도 등에 의한 것인지의 여부는 추가적인 검
토가 필요할 것으로 생각된다. '홍로' 품종의 사과 과실 크기에 영향을 미치는 요인으로는 최근 국내에서 발생하 고 있는 ASSVd(Apple scar skin viroid) 감염에 의한 것 도 있다. 이 ASSVd 감염과에서도 과실크기가 작아지는 경향이지만 바이로이드 감염과실은 과푀에 얼룩얼룩한 반 점이 나타나기 때문에(Lee 동, 2001; Osaki 등, 1996) 바 이러스에 의한 것과 구별은 가능하다. 이 밖에도 사과 과 실의 형태나 크기에 영향을 미친 바이러스병이나 바이로 이드병에 관한 보고는 많다. Parish(1976)는 과실이 납작 해지는 flat fruit 병징을 나타내는 사과에서 American cherry rasp leaf virus을 분리하였다고 보고하였으며, Palmiter(1970) 는 뉴욕주에서 발생한 flat fruit의 원인을 Apple green mottle virus라고 보고한 바 있다. 또한 고접병을 일으키 는 원인 바이러스인 Apple stem pitting virus 감염으로 접 목부의 이상증상 혹은 줄기에 pitting 증상이 나타나지만 과실의 크기도 작아지면서 비대가 억제되어 'flute fruit' 병징으로 구분한 기형과를 유발한다는 보고도 있다. 이 외에 과실 과피에 나타나는 russet, ringspot, crack 등의 현상들도 바이러스 혹은 바이로이드 병원체와 관련될 수 있으며(Koganezawa 등, 1983; Martyn, 1968; Welsh와 May, 1970, 1973) 일반적으로 바이러스 등 접목전염성 병 해의 감염은 과수작물에 있어 과실 품질저하 및 수량감 소예 의한 생산성 저하의 주된 피해요인으로 분석되고 있 다(Smith 등, 1972; Wood, 1979). 이러한 요인 외에도 과 실에 영향을 미치는 요인들은 매우 다양할 뿐만 아니라, 품종별로도 바이러스 및 바이로이드에 의한 감수성 정도 가 다를 것이므로 이에 대한 추가적인 연구가 계속적으 로 필요할 것으로 생각한다.

\section{요 약}

사과 ‘홍로' 품종은 품질이 우수하여 재배면적이 증가

Table 4. Influence of artificial infection of ACLSV and/or ASGV on fruit quality and fruiting in 'Hongro/M9' apple trees

\begin{tabular}{|c|c|c|c|c|c|c|}
\hline \multirow{2}{*}{ Sources of inoculation } & \multicolumn{2}{|c|}{$\begin{array}{l}\text { Absorbances of OD450 } \mathrm{nm} \text { by ELISA } \\
\text { (infection } \text { degree }^{z} \text { ) }\end{array}$} & \multicolumn{3}{|c|}{ Fruit quality } & \multirow{2}{*}{ Fruit response ${ }^{y}$} \\
\hline & ACLSV & ASGV & $\begin{array}{l}\text { Fruit weight } \\
\text { (g) }\end{array}$ & $\begin{array}{c}\text { Hardness } \\
(\mathrm{kg} / \varnothing 5 \mathrm{~mm}) \\
\end{array}$ & $\begin{array}{l}\text { Soluble solids } \\
\quad\left({ }^{\circ} \mathrm{Bx}\right)\end{array}$ & \\
\hline ACLSV & $1.052\left(++^{2}\right)$ & $0.282(-)$ & 212.5 & 2.77 & 12.5 & + \\
\hline ASGV & $0.140(-)$ & $0.545(+)$ & 225.0 & 2.87 & 14.5 & $+/-$ \\
\hline ACLSV+ASGV & $0.674(+)$ & $0.352(+)$ & 245.0 & 2.74 & 14.7 & - \\
\hline Fruit shrinking symptom & $1.575(+++)$ & $0.365(+)$ & 206.3 & 3.02 & 14.4 & + \\
\hline Virus-free & $0.106(-)$ & $0.214(-)$ & 255.0 & 2.84 & 15.2 & - \\
\hline
\end{tabular}

${ }^{z}++\sim++$, severe positive; + , moderate positive; - , negative.

${ }^{y}+$, small-fruits, $+/-$, not clear, - , normal-fruits. 
되고 있는 중요한 품종으로 최근 일부 농가에서 과실 크 기가 작아지면서 과육이 딱딱해지고 과즙이 거의 없어지 는 소과증상이 발생되고 있어 재배현장에서 문제가 제기 되고 있다. '홍로' 품종의 소과증상은 주요 재배지역에서 조사한 결과 조사농가당 홍로품종 재배주수의 평균 $12 \%$ 정도 발생되고 있었으며 ELISA에 의한 바이러스 진단 결 과 소과 발생나무에서 고농도의 ACLSV가 $100 \%$ 검출되 었다. 즙액 접종한 C. quinoa에서 ACLSV가 분리되었으 며, 접목 접종한 목본지표식물에서도 잎 상편생장 및 줄 기괴사 병징을 나타내어 접목전염성이 확인되었다. 소과 증상의 원인 구명을 위해 열처리와 생장점배양으로 육성 된 바이러스 무독주에 인위적으로 ACLSV 둥 바이러스 를 접목접종 한 다옴 결실된 과실의 특성을 조사한 결과 $\triangle$ ACLSV 접종주에서 소과증상이 발생되는 것을 확인할 수 있었다. 결론적으로, 소과증상을 일으키는 주된 요인이 $\triangle \mathrm{ACLSV}$ 감염에 의한 것으로 판단되며 국내 육성종인 '홍 로' 푺종은 $\mathrm{ACLSV}$ 에 대한 감수성 품종으로 분류될 수 있을 것으로 퐌단된다.

\section{참고문헌}

Alan, B., Karen, C., Michael, D., Adrian, G. and Leslie, W. 1995. Viruses of Plants ; Descriptions and lists from the VIDE Database. pp.100-102. CAB International.

김점국, 홍재성, 송기철, 최국선, 윤천종, 임명순. 1996. 수출용 과실의 고품질 안정생산예 관한 연구 : 과수 신육성 품종의 재배법 개선에 관한 연구. 농촌진홍청 원예연구소 시험연구 보고서, 292-305쪽.

김현란. 2001. 국내 과수 바이러스병 발생실태 및 방제대책. 연 구와 지도, 농촌진홍청, 42(11): 36-39.

김현란, 최용문, 임명순, 김규래. 1998. 사과나무의 바이러스 피 해와 목본 지표식물에 의한 바이러스 검정, 식물병리학회 추 계 프로시딩, 217쪽.

Koganezawa, H. Yanase, H. and Sakuma, T. 1983. Viroid-like RNA associated with apple scar skin (or dapple apple) disease. Acta Horticulturae 130: 193-197.

Lee, J. H., Park, J. K., Lee, D. H., Uhm, J. Y., Ghim, S. Y. and Lee,
J. Y. 2001. Occurrence of Apple scar skin viroid-Korean strain(ASSVd-K) in Apples cultivated in Korea. Korean J. Plant Pathol. 17(5): 300-304.

Martyn, E. B. 1968. Plant virus names. Phytopathological papers, No. 9, Kew: Commonwealth Mycological Institute, Kew, Surry.

Osaki, H., Kudo, A. and Ohtsu, Y. 1996, Japanese pear fruit dimple disease caused by apple scar skin viroid (ASSVd). Ann. Phytopathol. Soc. Japan, 62: 379-385.

Palmiter, D. H. 1970. Apple chat fruit symptoms produced by green mottle virus infection. Phytopathology 60: 577.

Parish, C. L. 1976. A comparison between the causal agents of cherry rasp leaf and flat apple diseases. Acta Horticulturae 67: 199-202.

신용억, 김휘천, 강상조, 문종열, 김정호. 1989. 사과 추석기 출 하용 우량품종 ‘홍로' 육성. 농시논문집(원예편). 31(3): 53-61.

Smith, P. R. and Challen, D. I. 1972. Aetiology of the rosette and decline diseases of peach and interactions between Prunus necrotic ringspot, Prune dwarf, and dark green sunken mottle viruses. Austr. J. Agric. Res. 23: 1027-1034.

Thomas, B. J. 1983. The particle length of an isolate of apple chlorotic leaf spot virus from Prunus domestica. Phytopath. Z. 106: 233-238.

Welsh, M. F. and May, J. 1970. Fruit wrinkle, a graft transmissible abnormality of Newtown apple. Plant Dis. Reptr. 54: 490-493.

Welsh, M. F. and May, J. 1973. Suppression of the symptoms of apple leaf pucker disease in an occurrence pattern that indicates virus interaction. Can. J. Plant Sci. 53(1): 137-145.

Wood, G. A. 1979. Virus and virus-like diseases of pome fruits and stone fruits in New Zealand. DSIR Bull. Wellington 226: 87.

Yanase, H., Sawamura, K., Yamaguchi, A. and Mink, G. I. 1975. Viruses causing applr topworking disease (Taka tsugi byo) in Japan. Acta Horticulturae 44: 221-230.

Yanase, H., Yamaguchi, A., Mink, G. I. and Sawamura, K. 1979. Back transmission of apple chlorotic leafspot virus (type strain) to apple, and production of apple topworking diseases symptoms in Maruba kaido (Malus prunifolia Borkh. var. ringo Asami). Ann. Phytopath. Soc. Japan 45(3): 369-374. 